\title{
Microbiological assay of amino acids in serum: valine, leucine, and methionine
}

\author{
J. A. BLACKMORE AND T. E. PARRY
}

From the Department of Clinical Pathology, Llandough Hospital, Penarth, Glamorgan, South Wales

SYNOPSIS A microbiological method for the assay of valine, leucine, and methionine in serum is described and its accuracy and reproducibility are assessed. Under the conditions specified the L-isomers only of the three amino acids are measured. The serum levels of the three amino acids in 60 normal subjects are presented.

Accurate methods for the quantitative determination of serum amino acids suitable for the clinical laboratory are not available. Procedures involving elution from paper chromatograms have in our experience shown poor reproducibility and low recovery rates and the column chromatography method of Moore and Stein (1954) requires expensive equipment. In the present communication we describe a microbiological procedure for the assay of valine, leucine, and methionine, which in our hands has given reproducible results and consistently high recovery rates. It is based on the microbiological assay medium described by Steele, Sauberlich, Reynolds, and Baumann (1949). Assay media, together with an instruction booklet ${ }^{1}$, for some 18 amino acids, including the three considered here, are available commercially.

\section{Materials and Methods}

\section{TEST ORGANISMS}

Streptococcus faecalis American Type Culture Collection strain no. 8043 (or the British equivalent Streptococcus species strain no. 6459 in the National Collection of Industrial Bacteria ${ }^{2}$ ) is used for the assay of both valine and leucine and Leuconostoc mesenteroides ATCC 8042 (Pediococcus acidilactici NCIB 6990) for methionine.

\section{MEDIA}

The test organisms are maintained as stab cultures in Bacto-Lactobacilli agar at $4^{\circ} \mathrm{C}$. A 24-hour culture

${ }^{1}$ Microbiological Assay of Vitamins and Amino Acids, Difco Laboratories, P.O. Box 14B Central Avenue, East Molesey, Surrey.

'Obtainable from the Torry Research Station, Aberdeen, Scotland. Received for publication 5 July 1971. in $10 \mathrm{ml}$ Bacto-Lactobacilli broth is centrifuged and the deposit resuspended in $20 \mathrm{ml}$ of sterile saline. Of the suspension $0.5 \mathrm{ml}$ is made up to $20 \mathrm{ml}$ with sterile saline. The inoculum consists of one drop of this final suspension. The appropriate Bacto-amino acid assay medium is used for the actual assay.

\section{AMINO ACID SOLUTIONS}

In the earlier part of the work the L-form of valine, but on account of their availability, the DL-forms of methionine and leucine were used. More recently the L-forms of all three amino acids have been used. One hundred mg'of L-valine and L-leucine and $50 \mathrm{mg}$ of L-methionine are dissolved in separate $100 \mathrm{ml}$ quantities of distilled water of AR purity. (If DLamino acids are used the quantities are doubled.) Working solutions are prepared by diluting $1.0 \mathrm{ml}$ of the above solutions to $100 \mathrm{ml}$ (valine and leucine) or $200 \mathrm{ml}$ (methionine) with distilled water. This gives a final concentration of $10 \mu \mathrm{g} / \mathrm{ml}$ (valine and leucine) and $2.5 \mu \mathrm{g} / \mathrm{ml}$ (methionine).

\section{GLASSWARE}

The assay tubes consist of Pyrex test tubes measuring $150 \times 16 \mathrm{~mm}$ fitted with aluminium caps. New unused sterile universal containers are used for the collection of blood and for the storage of culture media and sera. All glassware is chemically cleaned before sterilization.

Control sera were obtained in about $200 \mathrm{ml}$ quantities from the Welsh Regional Blood Transfusion Centre.' Normal sera were obtained from healthy volunteers, mainly hospital staff, and from a small number of otherwise healthy patients undergoing minor surgery. In an attempt to ensure as constant a metabolic state as possible all venepunctures were 
done immediately before the subjects received their midday meal (Parry, 1966; Parry, 1969). All sera were stored at $-20^{\circ} \mathrm{C}$.

\section{DEPROTEINIZATION}

Two methods of obtaining a protein-free filtrate were employed, precipitation by acetic acid (Hunter, 1957) and ultrafiltration. In the former $3.0 \mathrm{ml}$ of $0.05 \mathrm{~N}$ acetic acid is added to $3.0 \mathrm{ml}$ of serum. Nine $\mathrm{ml}$ of distilled water is added and the mixture placed in a boiling water bath for three to five minutes and filtered. The $p H$ of the filtrate is adjusted to that of the assay medium (6.8). One $\mathrm{ml}$ and 2.0 $\mathrm{ml}$ quantities of the filtrate-equivalent to $0.2 \mathrm{ml}$ and $0.4 \mathrm{ml}$ of serum-are used in each assay. Serum is ultrafiltered overnight through $8 / 32$ in. cellophane dialysis tubing, one end of which is sealed and the other connected to a compressed air cylinder from which a pressure of $10 \mathrm{lb}$ per square inch is maintained.

\section{Assay Procedures}

Increasing amounts of standard solution of the amino acid to be assayed are placed in the assay tubes as shown in Table I. Each serum is assayed at two different dilutions. All tubes are set up in triplicate and $2.0 \mathrm{ml}$ of double strength appropriate amino acid assay medium is added to each. After autoclaving at $10 \mathrm{lb}$ pressure for 10 minutes each tube is inoculated with the appropriate test organism and all are then incubated at $37^{\circ} \mathrm{C}$ for 17 hours. After thorough shaking the optical densities of the resulting growths as well as the inoculated blank (tube 1 in which there is no growth, due to the lack of an essential amino acid) are measured against water in an Optica CF4 spectrophotometer using $1 \mathrm{~cm}$ cuvettes at $600 \mathrm{~m} \mu$. The optical density of each triplicate set of tubes after subtracting the blank is plotted against the amino acid content per tube.
Results

ACID PRECIPITATION OF PROTEIN COMPARED WITH SERUM ULTRAFILTRATION

As acid precipitation of protein involved heating protein in an acid solution, it was thought advisable in view of the high degree of sensitivity of the method of amino acid assay employed to establish whether minute quantities of amino acids might be liberated as the result of minimal protein hydrolysis. Valine $\delta$ was therefore assayed in three sera on three different $\vec{\circ}$ occasions, each after deproteinization by acid precipitation and also after ultrafiltration. The results are shown in Table II. As there is no significant difference in the serum amino acid level ? following the two methods of deproteinization the $N$ acid precipitation method was used in the rest of the $\mathrm{i}$ work.

\begin{tabular}{|c|c|c|c|}
\hline Sera & Assay & $\begin{array}{l}\text { Ultrafiltration } \\
\text { (mg\%) }\end{array}$ & $\begin{array}{l}\text { Precipitation } \\
(\mathrm{mg} \%)\end{array}$ \\
\hline $\mathbf{A}$ & $\begin{array}{l}1 \\
\mathbf{2} \\
\mathbf{3}\end{array}$ & $\begin{array}{l}4 \cdot 2 \\
4 \cdot 2 \\
4 \cdot 3\end{array}$ & $\begin{array}{l}4.0 \\
3.9 \\
4.1\end{array}$ \\
\hline B & $\begin{array}{l}1 \\
2 \\
3\end{array}$ & $\begin{array}{l}2 \cdot 7 \\
2 \cdot 7 \\
2 \cdot 8\end{array}$ & $\begin{array}{l}2.6 \\
2.5 \\
2.6\end{array}$ \\
\hline C & $\begin{array}{l}1 \\
2 \\
3\end{array}$ & $\begin{array}{l}3 \cdot 3 \\
3 \cdot 7 \\
3 \cdot 7\end{array}$ & $\begin{array}{l}3 \cdot 4 \\
3 \cdot 4 \\
3 \cdot 5\end{array}$ \\
\hline Mean & & 3.51 & 3.33 \\
\hline
\end{tabular}

Table II Valine assay after two methods of deproteinization ${ }^{1}$

${ }^{1}$ Analysis of variance shows that despite the large difference between the sera there is no significant difference between the techniques. The $\supset$ coefficient of variation is $\pm 4 \%$ of the mean value $(F=3 \cdot 0, \mathrm{df}=1 / 12)$.

\section{REPRODUCIBILITY AND RECOVERY RATES}

During the three years that this work has been in $\frac{0}{3}$ progress a small number of different sera have been repeatedly used as controls. Their amino acid

\begin{tabular}{|c|c|c|c|c|c|c|c|c|}
\hline & \multicolumn{8}{|c|}{ Tube No. } \\
\hline & $l$ & 2 & 3 & 4 & 5 & 6 & 7 & 8 \\
\hline $\begin{array}{l}\text { Standard amino acid solution } \\
\text { (ml) } \\
\text { Water (ml) } \\
\text { Double strength assay medium } \\
\text { Amino acid ( } \mu \mathrm{g} / \text { tube) }\end{array}$ & $\begin{array}{l}0 \cdot 0 \\
2 \cdot 0 \\
2 \cdot 0\end{array}$ & $\begin{array}{l}0.2 \\
1.8 \\
2.0\end{array}$ & $\begin{array}{l}0.4 \\
1.6 \\
2.0\end{array}$ & $\begin{array}{l}0.6 \\
1.4 \\
2.0\end{array}$ & $\begin{array}{l}0.8 \\
1.2 \\
2.0\end{array}$ & $\begin{array}{l}1 \cdot 2 \\
0.8 \\
2 \cdot 0\end{array}$ & $\begin{array}{l}1 \cdot 6 \\
0.4 \\
2.0\end{array}$ & $\begin{array}{l}2 \cdot 0 \\
0.0 \\
2 \cdot 0\end{array}$ \\
\hline $\begin{array}{l}\text { Valine and leucine } \\
\text { Methionine }\end{array}$ & $\begin{array}{l}\mathbf{0} \\
\mathbf{0}\end{array}$ & $\begin{array}{l}2 \\
0 \cdot 5\end{array}$ & 4.0 & $\begin{array}{l}6 \\
1 \cdot 5\end{array}$ & $\begin{array}{l}8 \\
2 \cdot 0\end{array}$ & $\begin{array}{l}12 \\
3 \cdot 0\end{array}$ & $\begin{array}{l}16 \\
4 \cdot 0\end{array}$ & $\begin{array}{l}20 \\
5 \cdot 0\end{array}$ \\
\hline
\end{tabular}

Table I Assay procedure

${ }^{1}$ Each serum is assayed at two concentrations with $1 \mathrm{ml}$ of filtrate and $1 \mathrm{ml}$ of water $(=0.2 \mathrm{ml}$ of serum) and $2 \mathrm{ml}$ of filtrate $(=0.4 \mathrm{ml}$ serum) substituted for the standard amino acid solution in Table I. The average of the two dilutions is taken as the final result. As with the standard solutions each dilution of serum is assayed in triplicate. 


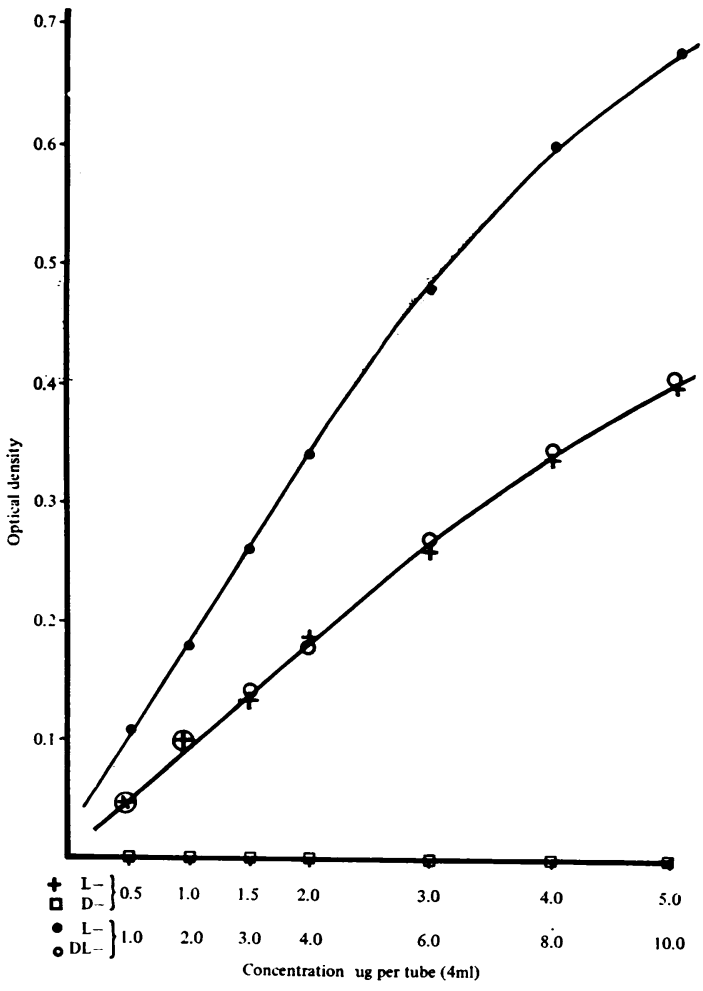

Fig. The growth-promoting properties of $D-, L$-, and DL-methionine (read at $700 \mathrm{m \mu}$ in view of the increased concentrations of L-methionine).

contents have, therefore, been assayed on several occasions and the results reflect the reproducibility of the method. These are shown in Table III. The results of recovery experiments are shown in Table IV.

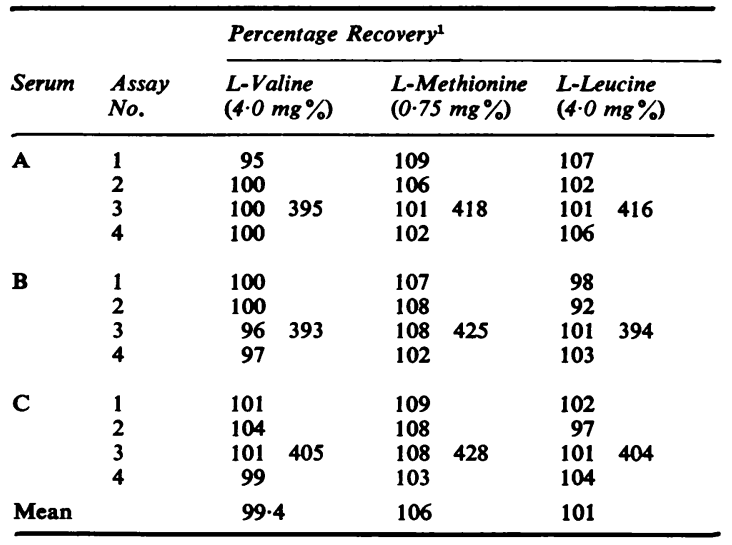

Table IV Recovery experiments

Coefficient of variation $= \pm 3.2 \%$

'Percentage recovery after adding $4 \mathrm{mg} \%$ of valine, $0.75 \mathrm{mg} \%$ of methionine, and $4.0 \mathrm{mg} \%$ of leucine separately to three different sera. Four experiments with each serum.

SERUM AMINO ACID LEVELS IN NORMAL SUBJECTS

Valine and methionine were assayed in the sera of 29 men and 30 women aged 20-60 years and leucine in 30 men and 30 women aged 20-83 years. The results according to age and sex are shown in Table V. All samples of venous blood were taken immediately before the midday meal.

Statistical analysis of the data was carried out by Professor H. Campbell of the Department of Medical Statistics of the Welsh National School of Medicine. In Tables II-IV the coefficient of variation is used as a measure of the efficiency of the method of assay so that each amino acid may be compared on a standard basis: coefficient of variation =

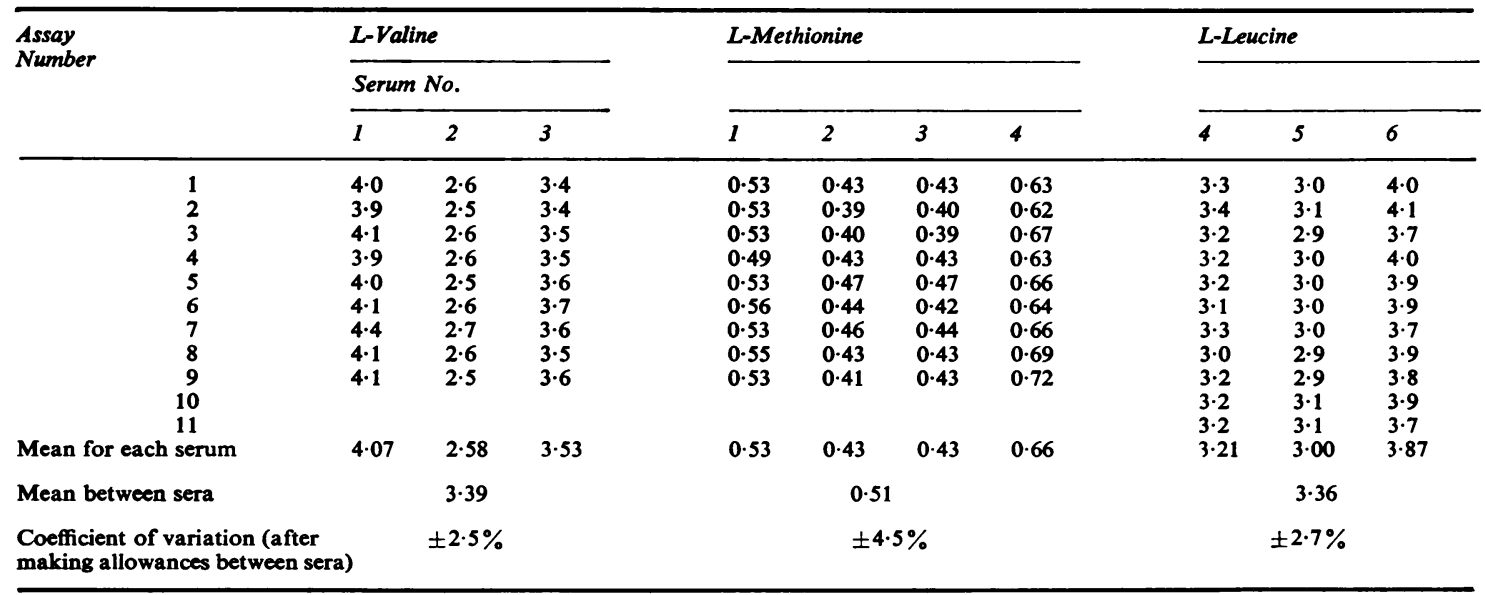

Table III Reproducibility of the method 


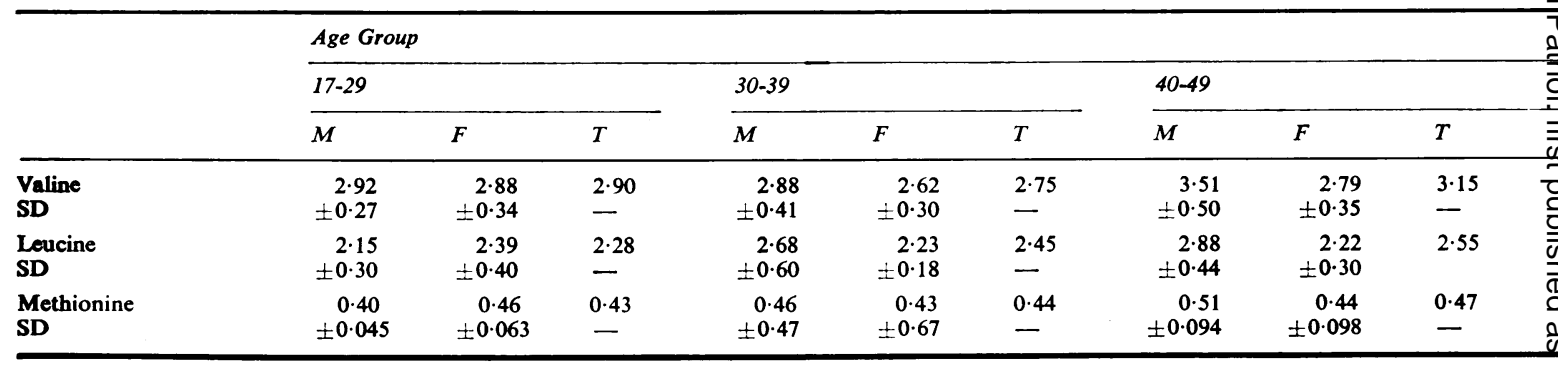

Table V Mean serum level of the three amino acids expressed as the L-form ${ }^{1}$

${ }^{1}$ Each value represents the mean in six men and six women in each decade (valine and methionine determined in only five men over 60 ).

standard deviation/mean value ${ }^{1}$. In Table IV where the quantity of amino acid to be recovered is $100 \%$ the coefficient of variation is the same as the standard deviation. In Table $\mathrm{V}$ where the observations are made on a group of individuals the variation between and within the groups is best estimated by the standard deviation.

\section{Discussion}

The cultural requirements of the microorganisms principally employed for amino acid assay, the Lactobacteriacae, have been reviewed by Shockman (1963) who found that Strep. faecalis did not respond to the D-isomers of valine and leucine. Lyman, Moseley, Butler, Wood, and Hale (1946) and Dunn, Camien, Shankman, and Block (1946) likewise found that D-methionine did not support the growth of $L$. mesenteroides. Other workers, however (Steele et al, 1949; Barton-Wright, 1961), have reported partial growth promoting activity of D-methionine for this organism. The D-

${ }^{1}$ Expressed as a percentage. isomers of the three amino acids failed to support the growth of the test organism under the conditions $N$ employed in the present work. The method therefore iv measures the L-isomer only of each amino acid $\overrightarrow{ }$ and the growth-promoting property of the L-isomer was exactly twice that of the DL-form in each case. This is illustrated in Fig. 1 in the case of methionine. D-methionine, however, did support the growth of $L$. mesenteroides when employed in higher concentration and incubated for considerably longer periods; thus growth in the highest concentration that we employed ( $5 \mu \mathrm{g} /$ tube) did not appear with this isomer until the tenth day of incubation.음

The reproducibility of the assay methods is withi the acceptable limits for the three amino acids. Th coefficient of variation is $\pm 2.5 \%$ for valine $\pm 4.5 \%$ for methionine and $\pm 2.7 \%$ for leucine. The slightly higher variation with methionine is probably due to the very low level of this amino acid in the four sera employed (mean value $0.51 \mathrm{mg}$ ).

The mean recovery rates for valine and leucine are 99.4 and $101 \%$ |respectively. There is, however, a slight tendency to overestimation in the case of

\begin{tabular}{|c|c|c|c|c|c|c|c|c|}
\hline & \multicolumn{8}{|l|}{ Author } \\
\hline & $\begin{array}{l}\text { Hier and } \\
\text { Bergeim } \\
(1946)\end{array}$ & $\begin{array}{l}\text { Steele, } \\
\text { Reynolds, and } \\
\text { Baumann } \\
(1950)^{1}\end{array}$ & $\begin{array}{l}\text { Schreier } \\
\text { and Plückthun } \\
(1950)\end{array}$ & $\begin{array}{l}\text { Johnson and } \\
\text { Bergeim } \\
(1951)\end{array}$ & $\begin{array}{l}\text { Stein and } \\
\text { Moore (1954) }\end{array}$ & $\begin{array}{l}\text { Iber, Rosen, } \\
\text { Levenson, and } \\
\text { Chalmers } \\
(1957)^{2}\end{array}$ & $\begin{array}{l}\text { Parry } \\
(1969)\end{array}$ & $\begin{array}{l}\text { Present } \\
\text { Authors }\end{array}$ \\
\hline Method & $\begin{array}{l}\text { Microbio- } \\
\text { logical }\end{array}$ & $\begin{array}{l}\text { Microbio- } \\
\text { logical }\end{array}$ & $\begin{array}{l}\text { Microbio- } \\
\text { logical }\end{array}$ & $\begin{array}{l}\text { Microbio- } \\
\text { logical }\end{array}$ & $\begin{array}{l}\text { Column } \\
\text { chromat- } \\
\text { ography }\end{array}$ & $\begin{array}{l}\text { Column } \\
\text { chromat- } \\
\text { ography }\end{array}$ & $\begin{array}{l}\text { Microbio- } \\
\text { logical }\end{array}$ & $\begin{array}{l}\text { Microbio- } \\
\text { logical }\end{array}$ \\
\hline $\begin{array}{l}\text { No. of } \\
\text { subjects }\end{array}$ & 33 & 4 & 11 & 24 & 5 & 17 & 16 & 60 \\
\hline Valine & $\begin{array}{l}2 \cdot 83 \\
( \pm 0 \cdot 34)\end{array}$ & $\begin{array}{l}3 \cdot 4 \\
(2 \cdot 8-3 \cdot 8)\end{array}$ & $\begin{array}{l}3 \cdot 05 \\
(2 \cdot 45-3 \cdot 65)\end{array}$ & $\begin{array}{l}2 \cdot 72 \\
( \pm 0 \cdot 39)\end{array}$ & $\begin{array}{l}2 \cdot 88 \\
(2 \cdot 37-3 \cdot 71)\end{array}$ & $\begin{array}{l}2 \cdot 70 \\
( \pm 0 \cdot 59)\end{array}$ & $\begin{array}{l}2.96 \\
( \pm 0.41)\end{array}$ & $\begin{array}{l}3.04 \\
( \pm 0.40)\end{array}$ \\
\hline Leucine & $\begin{array}{l}1 \cdot 91 \\
( \pm 0 \cdot 34)\end{array}$ & $\begin{array}{l}2 \cdot 4 \\
(2 \cdot 0-2 \cdot 6)\end{array}$ & $\begin{array}{l}2 \cdot 03 \\
(1 \cdot 68-2 \cdot 47)\end{array}$ & $\begin{array}{l}1 \cdot 86 \\
( \pm 0 \cdot 24)\end{array}$ & $\begin{array}{l}1 \cdot 69 \\
(1 \cdot 42-2 \cdot 30)\end{array}$ & $\begin{array}{l}1.53 \\
( \pm 0.07)\end{array}$ & - & $\begin{array}{l}2 \cdot 51 \\
( \pm 0.44)\end{array}$ \\
\hline Methionine & - & $\begin{array}{l}0 \cdot 9 \\
(0 \cdot 8-1 \cdot 1)\end{array}$ & $\begin{array}{l}0 \cdot 29 \\
(0 \cdot 15-0 \cdot 51)\end{array}$ & $\begin{array}{l}0.52 \\
( \pm 0.08)\end{array}$ & $\begin{array}{l}0.38 \\
(0.33-0.43)\end{array}$ & $\begin{array}{l}0.33 \\
( \pm 0 \cdot 07)\end{array}$ & $\begin{array}{l}0.93^{3} \\
( \pm 0 \cdot 11)\end{array}$ & $\begin{array}{l}0.45 \\
( \pm 0.075)\end{array}$ \\
\hline
\end{tabular}

Table VI Serum levels of valine, leucine, and methionine given by different authors

${ }^{1}$ Fasting levels in normal subjects receiving $100 \mathrm{~g}$ of protein per day.

${ }^{2}$ Expressed as $\mathrm{mg}$ of amino acids per $100 \mathrm{ml}$ of plasma ultrafiltrate

${ }^{3}$ Expressed as DL-methionine (see text). 


\begin{tabular}{|c|c|c|c|c|c|c|c|c|c|}
\hline \multicolumn{6}{|c|}{ Age Group } & \multirow[t]{3}{*}{ All Males } & \multirow[t]{3}{*}{ All Females } & \multirow[t]{3}{*}{ All Cases } & \multirow[t]{3}{*}{ Pooled SD } \\
\hline \multicolumn{3}{|l|}{$50-59$} & \multicolumn{3}{|l|}{$60-73$} & & & & \\
\hline $\boldsymbol{M}$ & $\boldsymbol{F}$ & $T$ & $M$ & $F$ & $T$ & & & & \\
\hline $\begin{array}{r}3.30 \\
\pm 0.55\end{array}$ & $\begin{array}{r}3.38 \\
\pm 0.21\end{array}$ & $\begin{array}{l}3 \cdot 34 \\
-\end{array}$ & $\begin{array}{r}2.96 \\
\pm 0.46\end{array}$ & $\begin{array}{r}3.18 \\
\pm 0.18\end{array}$ & $\begin{array}{l}3.07 \\
-\end{array}$ & $3 \cdot 12$ & $2 \cdot 97$ & 3.04 & 0.40 \\
\hline $\begin{array}{r}2.62 \\
\pm 0.40\end{array}$ & $\begin{array}{r}2.53 \\
\pm 0.41\end{array}$ & $\begin{array}{l}2 \cdot 58 \\
-\end{array}$ & $\begin{array}{r}2.58 \\
\pm 0.50\end{array}$ & $\begin{array}{r}2.80 \\
\pm 0.41\end{array}$ & $\begin{array}{l}2 \cdot 58 \\
-\end{array}$ & $2 \cdot 58$ & $2 \cdot 43$ & $2 \cdot 51$ & 0.44 \\
\hline $\begin{array}{c}0.45 \\
\pm 0.081\end{array}$ & $\begin{array}{c}0.48 \\
\pm 0.093\end{array}$ & $\begin{array}{l}0.46 \\
-\end{array}$ & $\begin{array}{c}0.41 \\
\pm 0.061\end{array}$ & $\begin{array}{c}0.49 \\
\pm 0.036\end{array}$ & $\begin{array}{l}0.45 \\
-\end{array}$ & 0.45 & 0.46 & 0.45 & 0.0755 \\
\hline
\end{tabular}

Table V-continued

methionine with a mean recovery of $106 \%$. This is relatively consistent varying from 101 to $109 \%$ in 12 experiments. Although this suggests some error of calibration we have not been able to trace it. The coefficient of variation or standard deviation (see above) for the recovery of the three amino acids is $\pm 3.2 \%$.

The mean serum levels of the three amino acids expressed as the $\mathrm{L}$-form are shown in Table V, where each value represents the mean in six men and six women in each decade except those over 60 where valine and methionine were determined in only five men. The mean serum levels in $\mathrm{mg} \%$ of the three amino acids in the entire group are: valine $3.04 \pm 0.40$, leucine $2.51 \pm 0.44$, and methionine $0.45 \pm 0.075$. These are in good agreement with values of $2.96 \mathrm{mg} \%$ and $0.93 \mathrm{mg} \%$ for serum valine and methionine respectively previously reported in 16 normal subjects (Parry, 1969). The latter was expressed as DL-methionine and is, therefore, numerically twice the value given here as L-methionine. There is no significant difference between age and sex in the serum value of leucine or methionine but detailed analysis of variance suggests that the difference in the valine levels between decades might be statistically significant $(P<0.05)$. This would imply that the serum valine concentration is highest in the decade 40-49 for males and 50-59 for females.

Table VI shows the previously reported serum levels of the three amino acids considered here.

We wish to thank Professor H. Campbell of the Welsh National School of Medicine for the statistical analysis, Dr Beryl Bevan of the Welsh Regional
Transfusion Centre for providing normal sera, and Mr R. W. Evans for the photograph.

\section{References}

Barton-Wright, E. C. (1961). Practical Methods for the Microbiological assay of the Vitamin B Complex and Amino Acids, p. 46. United Trade Press, London.

Dunn, M. S., Camien, M. N., Shankman, S., and Block, H. (1946). Investigations of amino acids peptides and proteins. J. biol. Chem., 163, 577-587.

Hier, S. W., and Bergeim, O. (1946). The microbiological determination of certain free amino acids in human and dog plasma. J. biol. Chem., 163, 129-135.

Hunter, G. (1957). A method for deproteinization of blood and other body fiuids. J. clin. Path., 10, 161-164.

Iber, F. L., Rosen, H., Levenson, S. M., and Chalmers, T. C. (1957). The plasma amino acids in patients with liver failure. J. Lab. clin. Med., 50, 417-425.

Johnson, C. A., and Bergeim, O. (1951). The distribution of free amino acids between erythrocytes and plasma in man. J. biol. Chem., 188, 833-838.

Lyman, C. M., Moseley, O., Butler, B., Wood, S., and Hale, F. (1946). The microbiological determination of amino acids. III. Methionine. J. biol. Chem., 166, 161-171.

Moore, S., and Stein, W. H. (1954). Procedures for the chromatographic determination of amino acids on four per cent cross linked sulphonated polystyrene resins. J. biol. Chem., 211, 893-913.

Parry, T. E. (1960). The amino acid content of venous blood and marrow aspirate before and after treatment in pernicious anaemia. Brit. J. Haemat., 12, 454-460.

Parry, T. E. (1969). Serum valine and methionine levels in pernicious anaemia under treatment. Brit. J. Haemat., 16, 221-229.

Schreier, K., and Plückthun, H. (1950) Untersüchungen über den Gehalt an freien Aminosäuren im Serum und Urin. Biochem. $Z$., 320, 447-465.

Shockman, G. D. (1963). In Analytical Microbiology, edited by F. Kavanagh, pp. 567-673. Academic Press, New York and London.

Steele, B. F., Reynolds, M. S., and Baumann, C. A. (1950). Amino acids in the blood and urine of human subjects ingesting different amounts of the same proteins. $J$. Nutr., 40, 145-158.

Steele, B. F., Sauberlich, H. E., Reynolds, M.S., and Baumann, C. A. (1949). Media for Leuconostoc mesenteroides P. 60 and Leuconostoc citrovorum 8081. J. biol. Chem., 177, 533-544.

Stein, W. H., and Moore, S. (1954). The free amino acids of human blood plasma. J. biol. Chem., 211, 915-926. 